\title{
Practical Analysis of Differential Equation Module to Improve Student's Logical Thinking Ability
}

\author{
Mujahidawati ${ }^{1}$, Gugun M.Simatupang ${ }^{2}$ Novferma $^{3}$, Ari Frianto ${ }^{4}$, Febbry \\ Romundza ${ }^{5}$
}

\author{
1,2,3,4 Jambi University \\ ${ }^{5}$ Jakarta State University \\ Email: mujahida.wati@unja.ac.id
}

\begin{abstract}
Students' ability to think logically is needed when making decisions in solving problems, making decisions from existing problems, and processing problems after being given a problem. This study aims to produce a practical differential equation module. This research is part of development research using the 4-D development model. The stages of developing the 4-D model consist of 4 stages, namely (1) define, (2) design, (3) develop, and (4) disseminate. This research only reached the practicality test of this product. It can be seen from the responses of 2 lecturers who have taught differential equations and 15 students and will be continued in the field trial stage. The research instrument consisted of individual test sheets (lecturer response questionnaire), and limited test sheets (student response questionnaires). Suggestions and comments from the lecturers and students' responses to the differential equation module learning were analyzed descriptively, while the data in the form of scores were analyzed descriptively quantitatively. The results of this study indicate that the small group trial on 2 lecturers (lecturer responses) met the very practical criteria, with an average score proportion of $89.6 \%$. While the results of the limited trial of 15 students (student response perception questionnaire) met the very practical criteria with an average score proportion of $84.48 \%$. So it can be denied that the product in the form of a differential module to improve logical thinking skills meets practical criteria and is feasible to apply.
\end{abstract}

Keywords: Practicality Module, Differential Equation Module, Logical Thinking Ability.

\section{INTRODUCTION}

Mathematics is a branch of science that can be applied to solve problems found in everyday life or in real life in an effort to understand other sciences. It is not surprising that mathematics subjects are taught from Elementary School (SD) to tertiary level [1]. Behind the role of mathematics which is considered so important in education, it turns out that there are still many students who find it difficult to understand mathematics courses in higher education. This is because most students think that mathematics courses in higher education are more difficult than maths that have been studied at previous levels of education. One of the mathematics courses in higher education is differential equations. Differential equations are a branch of mathematics that are widely used to describe physical problems. These physical problems can be modeled in differential equations [2]. Differential equations are used as a tool to determine the behavior and characteristics of the problem being reviewed. Therefore, as a student it is very important to learn differential equations. In solving the problems of differential equations, the ability to think at a higher level or think logically is needed.

A person's ability to think logically is an ability that can be used as an alternative to draw conclusions based on consistently agreed rules [3]. A person's ability to think logically plays an important role in mathematics with the aim of obtaining better learning achievement. Because the ability to think logically is the ability to think using logic, is rational and makes sense [4]. The ability of students to think logically is needed when making decisions in solving problems, drawing conclusions from available problems, and carrying out the problem-solving process after a problem is given. In accordance with mathematics courses that require logical thinking processes in solving problems, one of which is the differential equation course in higher education. However, the facts and facts that occur are that students, especially mathematics education students, still have the ability to think logically which can be said to be low. 
Most of the students have not been able to make the right decisions and are not able to learn independently in solving a math problem given in class. Supported based on the acquisition of preliminary observations that have been made on students of 2018 mathematics education in different classes with 10 students during the learning process in differential equations courses. The results of these preliminary observations are presented in table 1 below:

Table 1. Results of Preliminary Observation of Students' Logical Thinking Ability

\begin{tabular}{lccc}
\hline No & Ability & Indicator & Number of students (person) \\
\hline 1 & & Make decisions & 3 \\
2 & Think Logically & Draw a conclusion & 4 \\
3 & & solution to problem & 3 \\
& & & 10 \\
\hline
\end{tabular}

Based on table 1 above, it can be seen that of the 10 students observed, not all students were able to meet the indicators of logical thinking abilities. It can be seen that there are only 3 students or only $30 \%$ who are able to make decisions in solving problems. There were only 4 students or only $40 \%$ who were able to draw conclusions correctly when solving problems and there were only 3 students or $30 \%$ of students who were able to solve problems correctly.

Many factors cause the students' lack of understanding of mathematics and the low ability of students to think logically. One of them is the teaching tools or materials used in the learning process. The process to improve students' logical thinking skills must be supported by the ability of the teaching staff (lecturers) to create or design new innovations in the learning process to be carried out.

Teaching materials are all materials (information, tools and texts) that have previously been arranged regularly (systematically), wherein is displayed a competency that will be mastered by students and which will be used by students in the implementation of the learning process which will be carried out with the aim of planning and studying in implementation of the learning process that will be carried out is successful, one of which is the module [5]. Module is one of the teaching materials that is classed as a whole and systematically, in which a module contains a set of learning experiences that are planned and designed to help module users master the objectives of learning [6].

In fostering character, apart from using the learning model, it can also be through the development of media and textbooks. For example, there are research results that try to develop logic-based learning media.
The results show that logic-based media has a positive impact in fostering children's creativity and intelligence [7]. Facts and facts that occur in the field, the modules used in the learning process carried out in tertiary institutions are modules published by the government and there are no additional learning resources intended for students to study independently. So that the existing modules cannot be used as a means used to train students' logical thinking skills. To overcome this, it is necessary to have new innovations designed by the teaching staff, namely designing a module that contains a learning model that can improve thinking skills. student logical and in accordance with student characteristics and abilities. Developing a differential equation module should use a learning model that can make students actively learn independently and a learning model that can be used as an alternative to support students' ability to think logically. because in the process of implementing learning that is carried out in the classroom there is still no finding of a module that is used as a guide book for students in the implementation of learning carried out with differential equations courses that can make students actively learn independently.

\section{METHODS}

This research is part of development research, where this development produces a product in the form of a differential equation module to improve students' logical thinking skills by using a problem-based learning model. This study uses a 4-D development model, where the development stage of the 4-D model consists of 4 stages, namely (1) definition, (2) design, (3) development, and (4) dissemination (dissemination). This research only reached the practicality test and did 
not reach the field test. The research instruments used were 1) the lecturer response questionnaire; and 2) questionnaire for student responses. The trial is limited to seeing the practicality of the product being developed, namely with 2 lecturers in different schools and 15 students from different schools as test subjects. Where 15 test subjects are in accordance with the student's ability level (low, medium, high).
Practicality data analysis was obtained from response questionnaire instruments in limited trials or small group trials where the scoring used a Likert scale to measure negative or positive responses made with intervals of 1-5. The guidelines for the response of lecturers and student questionnaires are listed in table 2. below [8]:

Table 2. Practicality Instrument Scoring

\begin{tabular}{|c|c|c|}
\hline Score & Category & Percentage of Achievement Indicators \\
\hline 5 & Very Agree & $81 \%-100 \%$ \\
\hline 4 & Agree & $61 \%-80 \%$ \\
\hline 3 & Enough Agree & $41 \%-60 \%$ \\
\hline 2 & Less Agree & $21 \%-40 \%$ \\
\hline 1 & Disagree & $0 \%-20 \%$ \\
\hline
\end{tabular}

Furthermore, the practicality analysis of the Response Questionnaire in a limited trial was determined through the following data analysis techniques [9]:

Information:

$$
P=\frac{\sum \boldsymbol{x}}{\sum \boldsymbol{n}} \times 100 \%
$$

$V=$ Validity Value

$\sum \boldsymbol{x}=$ Total Score obtained

$\sum \boldsymbol{n}=$ Maximum total score

\section{RESULTS AND DISCUSSION}

The limited trial of the product that has been developed by the researcher, namely the differential equation module through the Guided Discovery Learning model to improve students' logical thinking skills is carried out after the product is declared valid. This differential equation module is tested in class. Guided Discovery Learning model encourage participants students to find clues or evidence, the results of the analysis, and make a determination regarding possible conclusions which is useful for connecting between learning material components [10]. The guided method of recovery learning has a significant influence on fluency, creativity and development [11]. At the development test stage, this will be carried out through product testing to determine the practicality and effectiveness of the product, namely the differential equation module that has been developed.

\section{Practicality Test for Differential Equations Module} After the validation process is complete, then field trials are carried out. The trial was carried out in the mathematics education study program in the subject of differential equations, FKIP Jambi University. Practicality data were taken from questionnaire responses from lecturers and students during learning using the differential equation module through Guided Discovery Learning to improve students' logical thinking skills. A lecturer response questionnaire was given to one of the educators / lecturers and a student response questionnaire was given to 15 students who were selected into the research class concerned to determine the practicality of the module through Guided Discovery Learning to improve students' logical thinking skills that had been used.

The small group test was carried out online and offline, online through the zoom meeting platform, while offline (home to students). In the small group trial, students will be given a hard copy differential equation module to make it easier for students to read and understand the material, then the researcher will provide an explanation of the sub-material to be studied, instructions for use, competencies to be achieved, and general description of the material to be studied. Furthermore, the researcher asked students to read and examine the differential equation module that had been given.

After studying and observing the differential equation module that has been given, students will be given a response questionnaire to the module, this student response questionnaire contains 24 statements. 
The giving of student response questionnaires that have been made by researchers will be done by filling out Google Forms online. The results obtained from giving student response questionnaires to small groups can be seen in table 3 below:

Table 3. Results of the Practicality Questionnaire Assessment by Students

\begin{tabular}{|c|c|c|}
\hline No & Statement & Score \\
\hline 1 & The level of vocabulary contained in the module is easy to understand. & 34 \\
\hline 2 & The sentences used are easy to understand. & 36 \\
\hline 3 & $\begin{array}{l}\text { The introductory sentence delivered at the beginning of each sub-material is in accordance } \\
\text { with the material. }\end{array}$ & 36 \\
\hline 4 & Each sub-material in the module is closely related. & 36 \\
\hline 5 & $\begin{array}{l}\text { Reading the conclusions / summaries in the module can help to understand the material } \\
\text { well }\end{array}$ & 35 \\
\hline 6 & The context of the material presented relates to everyday life. & 34 \\
\hline 7 & The examples given are in accordance with the material. & 36 \\
\hline 8 & The material presented in the module can make you think well. & 31 \\
\hline 9 & The illustrations are illustrated according to the information in the module. & 32 \\
\hline 10 & The material exposure is in order of good order. & 35 \\
\hline 11 & The steps for presenting the material in the module are clear. & 36 \\
\hline 12 & The material contained in the module is presented in various ways & 32 \\
\hline 13 & $\begin{array}{l}\text { The information presented in the module can make it easier to understand the content of } \\
\text { the material }\end{array}$ & 32 \\
\hline 14 & $\begin{array}{l}\text { Guided Discovery Learning model based modules are able to improve students' logical } \\
\text { thinking skills }\end{array}$ & 35 \\
\hline 15 & $\begin{array}{l}\text { modules based on the Guided Discovery Learning model (Guided Discovery) make you } \\
\text { more motivated to learn. }\end{array}$ & 33 \\
\hline 16 & $\begin{array}{l}\text { modules based on the Guided Discovery Learning (Guided Discovery) model make you } \\
\text { learn independently. }\end{array}$ & 31 \\
\hline 17 & The working procedures contained in the module are easy to learn. & 31 \\
\hline 18 & Feel happy with the use of modules that can improve students' logical thinking skills & 35 \\
\hline 19 & Module design according to student level & 37 \\
\hline 20 & Module material is in accordance with the development of student abilities. & 32 \\
\hline 21 & the modules developed make students free to explore. & 32 \\
\hline 22 & the module developed can motivate students to learn. & 35 \\
\hline 23 & $\begin{array}{l}\text { By using a module based on Guided Discovery Learning (Guided Discovery), it can } \\
\text { shorten learning time. }\end{array}$ & 33 \\
\hline \multirow[t]{4}{*}{24} & modules developed in accordance with the learning environment. & 32 \\
\hline & Amount & 811 \\
\hline & Percentage $(\%)$ & $84,48 \%$ \\
\hline & Criteria & Practical \\
\hline
\end{tabular}

It can be seen from table 3 above, it is found that the score of the student practicality assessment is 811 out of a maximum score of 960 , from this score the average score is 4.22 . The percentage of practicality is $84.48 \%$ with the practicality criteria "Very Practical" or can be used without revision. From the practicality assessments that have been obtained from individual trials and small group trials, it can be determined that the overall practicality assessment of the differential equation module that has been made is as follows: 
Table 4. Percentage of Practicality Questionnaires by Educators and Students

\begin{tabular}{|c|c|}
\hline Assessment Aspects & Percentage of Practicality \\
\hline $\begin{array}{l}\text { Questionnaire Results of Lecturer Response } \\
\text { Practicality }\end{array}$ & 89,6 \\
\hline $\begin{array}{l}\text { Questionnaire Results of Student Response } \\
\text { Practicality }\end{array}$ & 84,48 \\
\hline Amount & 174,08 \\
\hline Average (\%) & $87,04 \%$ \\
\hline Criteria & Very Practical \\
\hline
\end{tabular}

Based on table 4 above, it can be seen that the average percentage of practical assessment instruments by lecturers and students is $87.04 \%$ with the category "Very Practical". This is evidenced by the instrument's average value in the range of $85.01 \%$ to $100.00 \%$. Based on these data, it can be concluded that the teaching material is in the form of a differential equation module which has been designed to be very practical to use and can facilitate students during the learning process. From the results of the analysis of the two questionnaires, namely the lecturer response questionnaire and the student response questionnaire, it was found that an average of $87.04 \%$ was categorized as very practical. Thus it can be concluded that the teaching materials that have been used in the form of a differential equation module are very practical to use and help and facilitate students in the learning process.

\section{CONCLUSION}

The practicality assessment was obtained during individual trials by providing a questionnaire on the response of educators (lecturers) who had taught differential equation subjects, the assessment score was 63 and the percentage of practicality was $89.6 \%$ with the criteria "Very Practical and when testing small groups carried out to 15 Students with different levels of students' logical thinking ability, obtained an assessment score of 811 and a practicality percentage of $84.48 \%$ with the criteria "Very Practical". Based on the value obtained, the overall practicality percentage is $87.04 \%$ with the criteria obtained is "Very Practical". Therefore it can be concluded that the teaching material product in the form of a differential equation module through the guided discovery learning method to improve students' logical thinking skills meets very practical criteria, so that it can be said that the developed module can continue to the next stage to see the effectiveness and the module is feasible in the learning process.

\section{REFERENCES}

[1] Supatmono, Catur. 2009. Matematika Asyik. Jakarta: PT Grasindo

[2] Siregar, Rosliana. 2012. Persamaan Differensial Eksak Dengan Faktor Integrasi. Journal of Mathematics Education and Science, 68-80.

[3] Septiati Eti. 2016. Kemampuan Berpikir Logis Matematis Mahasiswa Pendidikan Matematika Pada Mata Kuliah Matematika Diskrit. 1(1). 394-401.

[4] Irwansyah dan Lubis, AM. 2015. Pengaruh Kemampuan Berpikir Logis dan Motivasi Berprestasi Terhadap Prestasi Belajar Ekonomi Siswa Kelas X SMA Swasta Yayasan Pendidikan Nur Azizi Tanjung Morawa T.P 2015/2016. Jurnal Niagawan, 26-30.

[5] Prastowo, Andi. 2014. Pengembangan Bahan Ajar Tematik:Tinjauan Teoritis dan Praktik. Jakarta: Prenadamedia Group.

[6] Daryanto. 2013. Inovasi Pembelajaran Efektif. Bandung: Yrma Widya.

[7] Sulchan, Ali.2014. Pengembangan Media Pembelajaran Berbasis Logika dan Kreativitas sebagai Peningkatan Kecerdasan Anak Usia Dini. Tersedia pada http//p4tksb-jogja.com/arsip/index.php? option-Ali Sulchan- Pengembangan media berbasis logika. 
[8] Siregar, Rosliana. 2012. Persamaan Differensial Eksak Dengan Faktor Integrasi. Journal of Mathematics Education and Science, 68-80.

[9] Lestari Ika. 2013. Pengembangan Bahan Ajar Berbasis Kompetensi. Padang: Akademia Permata.

[10] Walsh, J. A., \& Sattes, B. D. (2011). Thinking Through Quality Questioning: Deepening Student Engagement. United States of America.

[11] Gholamian, A. (2013). Studying the effect of guided discovery learning on reinforcing the creative thinking of sixth grade girl students in qom during 2012- 2013 academic year. Journal of Applied Science and Agriculture, 8 (5). 576-584. 